Article

\title{
Writing a Recipe for Teaching Sustainable Food Systems: Lessons from Three University Courses
}

\author{
Christy Anderson Brekken ${ }^{1, *(\mathbb{D})}$, Hikaru Hanawa Peterson ${ }^{2}$, Robert P. King ${ }^{2}$ and David Conner ${ }^{3}$ \\ 1 Department of Applied Economics, Oregon State University, 228 Ballard Extension Hall, \\ Corvallis, OR 97331, USA \\ 2 Department of Applied Economics, University of Minnesota, 231 Ruttan Hall, 1994 Bufford Ave., \\ St. Paul, MN 55108, USA; hhp@umn.edu (H.H.P.); rking@umn.edu (R.P.K.) \\ 3 Department of Community Development and Applied Economics, University of Vermont, \\ 205H Morrill Hall, Burlington, VT 05405, USA; david.conner@uvm.edu \\ * Correspondence: christy.anderson.brekken@oregonstate.edu
}

Received: 15 May 2018; Accepted: 4 June 2018; Published: 6 June 2018

check for updates

\begin{abstract}
The sustainability of the food system is at the forefront of academic and policy discussions as we face the challenge of providing food security to a growing population amidst environmental uncertainty and depletion, social disruptions, and structural economic shocks and stresses. Crafting a sustainable and resilient food system requires us to go beyond disciplinary boundaries and broaden critical and creative thinking skills. Recent literature calls for examples of pedagogical transformations from food systems courses to identify successful practices and potential challenges. We offer a recipe for what to teach by framing systems thinking concepts, then discuss how to teach it with five learning activities: deductive case studies, experiential learning, reflective narrative learning, system dynamics simulations and scenarios, and inductive/open-ended case studies, implemented with collaborative group learning, inter/trans-disciplinarity, and instructor-modeled co-learning. Each learning activity is animated with concrete examples from our courses at Oregon State University, University of Minnesota, and University of Vermont, USA. We discuss opportunities and challenges implementing these strategies in light of student, instructor, and institutional expectations and constraints. But the challenge is worth the effort, because food system transformation requires active learners and systemic thinkers as engaged citizens, food system advocates, entrepreneurs, and policy makers.
\end{abstract}

Keywords: food systems; sustainability; undergraduate education; graduate education; system thinking; applied economics; interdisciplinary; transdisciplinary; reflective learning; collaborative learning

\section{Introduction}

The sustainability of the food system is coming to the forefront of academic and policy discussions. We face the challenge of providing food security to a growing population amidst short-run shocks and long-term stresses to the system. These include environmental uncertainty and depletion arising in part from impacted agricultural systems, social disruptions from resource conflicts, and structural economic shocks and stresses such as chronic income inequality. Crafting a sustainable and resilient food system requires us to face wicked problems that go beyond disciplinary boundaries, broaden critical and creative thinking skills, and engage in food system capacity building [1-6].

Undergraduate and graduate students are poised to engage the wicked problems of the food system, putting university education to the task of supplying the tools and knowledge that they need through interdisciplinary food systems or sustainable agriculture programs at universities [1,7-11]. Food system work is springing from colleges of agriculture in the agro-ecological or environmental sciences disciplines, incorporating social science disciplines that bring in dimensions of culture and 
justice, public health and nutrition, agricultural economics, public policy and planning, and others. A key goal for a food systems course or program is to bring the complex universe of food system actors, interconnections, and their social, economic, and environmental outcomes under one umbrella, which can be accomplished with a focus on systems thinking concepts.

Valley et al. [1] and Hilimire et al. [8] provide recent systematic reviews of sustainable food systems programs, which have begun to write a recipe for food systems courses by proposing signature pedagogy and successful approaches. Responding to Valley et al.'s [1] recommendation to share examples of pedagogical transformations, our goal is to put some "meat on the bones" of the food systems pedagogy literature with concrete examples from our university food systems courses taught at Oregon State University, University of Minnesota, and University of Vermont, USA, all housed in Applied Economics Departments but teaching food systems courses that serve undergraduate and graduate interdisciplinary degree programs. The history and student population served for each of the courses is detailed in Section 2.

If the goal of food systems education is to equip students to tackle complex food systems problems, educators must embrace "fundamental changes in both what and how we teach" [10] (p. 44). In Section 3, we first delineate what to teach by isolating the necessary systems thinking concepts that are identified as the key ingredients for food systems courses, framed through our experience teaching these concepts through an applied economics lens $[1,8]$. Then, we address how to teach systems thinking by proposing a framework of five learning activities and three implementation strategies that emerge from the food system pedagogy literature. To operationalize the recommended pedagogy in the food systems literature, we provide examples of how we use these learning activities and implementation strategies in our food systems courses. In Section 4, we reflect on the opportunities and challenges inherent in providing transformative learning opportunities in food systems courses. While our universities offer full food systems programs, our food systems courses are core classes in that education, and are often attended by students who are not participating in the full programs. By focusing on our core food systems courses, we embrace the challenges and opportunities to impact a wide range of students in a variety of disciplines, who are the future food system citizens, consumers, professionals, advocates, and policy makers $[1,3,8]$.

\section{Review of University Food Systems Offerings in 3 Courses}

Valley et al. [1] recently developed a signature pedagogy for food systems programs based on flagship sustainable food systems programs in the United States. Our contribution to the food systems pedagogy framework is based on our experience teaching food systems courses. Here we provide a brief history of each course, along with the programs that are served and typical enrollment. We also discuss the types of students that enroll in the courses to demonstrate the interdisciplinary audience, and how applied economics as a discipline is used to frame each course, which is a key unifying theme discussed throughout.

\subsection{Oregon State University (OSU), AGRI 411/511 Introduction to Food Systems, Local to Global}

Oregon State University first offered a Food Systems course in 2012 as a collaborative effort, funded and cross-listed across six departments and the College of Agricultural Sciences (Animal Science, Applied Economics, Crop and Soil Science, Horticulture, Food Science and Technology, and Anthropology in the College of Liberal Arts). Undergraduate and graduate sections are combined into one course offering. In 2014, it was listed under a single permanent course designator under the College of Agricultural Sciences (AGRI 411/511). In 2016, it became a Baccalaureate Core Course (BACC) in the Science, Technology, and Society category (all students must take one course with this designation for graduation). It is a required core course in the Food in Culture and Social Justice (FCSJ) program, which has both an undergraduate certificate program and a graduate minor, and the course satisfies requirements for a variety of minors and options from the College of Agricultural Sciences or College of Earth, Ocean, and Atmospheric Sciences. In 2017, an Ecampus section of the class (fully online delivery) was first offered. The course is now taught on-campus in the winter term and via 
Ecampus in the winter and summer terms; each section enrolls 30-40 students, with fewer than five graduate students per term.

Food Systems was designed to be interdisciplinary, but the lead instructor has always been in the Department of Applied Economics, and as such, an economic lens has shaped the framework and content. The topics are organized along the steps of the food supply chain from production to consumption, with overarching themes such as systems thinking and economic, environmental, and social impacts emerging throughout. While the majority of students come from the agricultural sciences departments, a minority of students from other departments, particularly students from the FCSJ program, join the class each year to bring a diversity of viewpoints into course interactions.

\subsection{University of Minnesota (UMN), APEC 3202, An Introduction to the Food System: Analysis, Management, and Design}

The University of Minnesota first offered this course in 2014 in the Department of Applied Economics as a required core course for the newly established Food Systems undergraduate major. The course was also approved for designation as an interdisciplinary course for the College of Agricultural, Food and Environmental Sciences (CFANS). The enrollment has fluctuated around 55 students.

All Food Systems majors are required to take this course. In addition, students from other majors, especially Applied Economics and Agricultural and Food Business Management, take the course to satisfy the CFANS interdisciplinary course requirement. In its original conception, the course was organized around three aspects of systems thinking: (1) analysis is the identification of the elements, interconnections, and purpose of a system; (2) management is the manipulation of system inputs for a given system to achieve its desired performance; and (3) design is the modification of elements and interconnections in a system to transform its performance.

\subsection{University of Vermont (UVM), CDAE/FS 321, Economics of Sustainable Food Systems}

The University of Vermont has offered a cross-listed graduate-level class in the Food Systems and Applied Economics programs as an elective course since 2012. Because it is a graduate-level elective course, enrollment typically ranges from 5 to 10 students.

As a course that is cross-listed in both Food Systems and Applied Economics departments, it draws students from those departments plus a handful from Natural Resources, Plant and Soil Science, and Public Administration. The goal is to use an economics lens to examine the food system as a whole including production, consumption and distribution systems, recognizing that students come from a diversity of academic backgrounds. Lack of sustainability is framed as resulting from externalized social, economic, and environmental costs, asymmetric information, or the failure to provide adequate public goods; sustainability is an effort to correct those market failures. Finally, it emphasizes that any effort to enhance sustainability has inherent tradeoffs among social, economic, and environmental impacts.

\section{A Recipe for Teaching Food Systems: What to Teach and How to Teach It}

Any recipe has two parts: the ingredient list and preparation method. A cook needs to know what to put into the dish, because you cannot make an omelet without eggs. But a cook also needs to know what to do with the eggs: Breaking and disposing of the shell, whipping, heating and cooking in a skillet until the correct consistency, and flipping the omelet takes practice-it is not a simple operation that can be perfected after reading a bit of text. Just as in writing a recipe, including the correct concepts, using the right learning activities, then applying hands-on modeling and practice are integral parts of the food systems learning experience for instructors and students.

A successful recipe for food systems pedagogy is emerging from the literature, identifying both ingredients-what to teach, and methods-how to teach it $[1,8]$. The key ingredient of a food systems course is a systems thinking framework that is the foundational "deep structure" of the course $[1,3,12]$. But to call it a "deep structure" does not mean that systems thinking concepts should 
be incorporated only implicitly; students should be consciously aware of the systems thinking skills that they are acquiring and applying. We will first give examples from our courses to demonstrate how systems thinking is explicitly incorporated throughout a food systems course by detailing the structure of systems thinking that we introduce to students, and how our applied economics lens supports the concepts.

Next we review the methods-how to teach-for teaching systems thinking that emerge from the food systems pedagogy literature. We synthesize the literature to distill five learning activities used to elucidate the systems thinking concepts, then break out implementation strategies used to reach the implicit goals of food systems courses: collective action, critical reflection, and seeking balance [1]. We then provide examples of how we teach systems thinking concepts in our courses using the recommended learning activities and implementation strategies from the literature.

\subsection{What to Teach: Systems Thinking Concepts}

Systems thinking must be taught explicitly in a food systems class, which is accomplished by first teaching a framework for analyzing a system. A system is much more than a sum of its parts, just as an omelet is much more than eggs, whisk, and heat. A system is "[I] a set of elements or parts that is [II] coherently organized and interconnected in [III] a pattern or structure that produces a characteristic set of behaviors, often classified as its 'function' or 'purpose'" [13] (p. 188). The elements of the system are most obvious, but often least crucial to understanding the dynamics of the system. To understand the system, we examine the forces that interconnect the elements, and from interconnections to the dynamics that give rise to system outcomes. System outcomes are both the system function or purpose - in the case of food systems, to produce and deliver food to the population—but also the unintended consequences that arise from the system, such as environmental degradation, obesity alongside food insecurity, resource conflicts, and others [12]. As with any conceptual thinking, the abstract nature of systems thinking can be challenging for students. Illustrating abstract concepts by creating concrete analogies to lived experience-such as writing an omelet recipe to illustrate designing a food systems class-is a simple but effective way to reach students who are grounded in the daily realities of food but are learning to analyze, manage, and influence a food system.

\subsubsection{A Set of Elements or Parts}

The food supply chain is a useful organizing tool for revealing food system elements, actors, and forces, which is natural coming from an applied economics discipline (Figure 1). Students of all disciplines have some familiarity with the actors that move food from farm to plate: farmers, processors, wholesalers, retailers, food service providers, marketers, and consumers. But many may not have considered additional actors and influences on the system: government, nutritionists, agricultural technologists, investors, advocacy groups, transportation, international trade organizations. There are non-human parts of the chain as well: land, water, energy, natural and synthetic inputs, climate, and weather.

\section{Food System Elements}

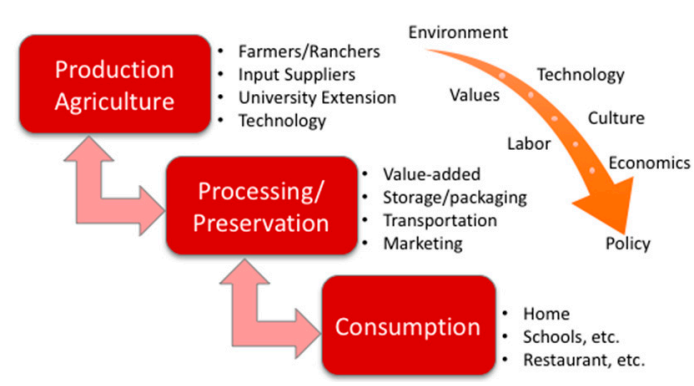

Figure 1. Food system elements representing the supply chain and overarching system forces used in OSU AGRI 411/511, to orient students to basic food system elements. 
Identifying these stakeholders in the system is the first and easiest step in the systems thinking process. However, the key stakeholders who contribute to or bear the benefit and cost of the system are sometimes not obvious. For example, policy interventions in the United States (such as the Supplemental Nutrition Assistance Program (SNAP)) or outcomes that prompted those policy responses imply that everyone shares the cost and potentially receives direct and indirect benefits from the program. Recognizing that goals differ across actors, and different actors have a past, current, and potentially future interaction with a food system component is a key insight for students.

\subsubsection{Coherently Organized and Interconnected in a Pattern or Structure}

The next step is understanding how the system actors interact, including the physical, social, and institutional forces affecting system elements [1,13]. All of these forces, both from inside and outside the food supply chain, organize and interconnect the food supply chain into a working system with a characteristic structure. Unless these forces are explicitly taught, they may remain invisible to students who focus on the elements.

Interconnections in the food system are location dependent and time specific. Examples can be elicited by asking about the role and position of other elements in the system at a given scale, place, and time. This is a process or action concept. Students must ask how the system actors affect each other, and how the interconnection between the parts produces an outcome through the forces interconnecting the elements: natural or physical forces, social or cultural forces, and institutional forces such as law and economics. Some students struggle to consider the interconnections between two elements in isolation of other variables. Once grasped, it is quite remarkable how a wide range of system behavior can emerge from a collection of simple interconnections.

The concept of feedback is critical for understanding interconnections and the ways in which system structure has a fundamental impact on system outcomes. Feedback loops exist when a stock or variable changes in a predictable way based on the state of the variable itself [13]. They can be balancing or reinforcing-i.e., they can either stabilize changes in the system toward an equilibrium level or amplify and reinforce changes. Feedback loops in the food system can make it resistant to change or they can drive rapid changes in unexpected directions if they are not recognized.

To push thinking on system dynamics, we ask which of the system forces is changeable, because people have influence over all of these forces over different temporal and spatial scales. For example, natural forces include temperature and rainfall patterns that determine which crops can be grown in different parts of the world; however, plant and animal breeding, climate control, and landscaping are ways that humans have pushed the boundaries of natural limitations. On the other hand, human activities have released greenhouse gases that are changing the global climate, in part through agricultural production, and although we can mitigate and adapt, the effects will play out, often through reinforcing feedback loops, over a timescale that will have major impacts on our food system going into the future.

Introducing students to temporal patterns for key food system elements adds to understanding about the inherently dynamic nature of the food system. Over the last 250 years, food systems have evolved dramatically from hunter-gatherer and subsistence agriculture systems to the global, mechanized and industrialized system we observe today. Technological developments such as mechanization, rail and later truck transport, food preservation technologies, and communications technologies that supported chain store operations and advertising have all had transformative impacts on the food system. Similarly, societal changes such as urbanization and the sharp growth in workforce participation by women have also had profound effects on the food system. Environmental impacts such as those induced by climate change are also best understood from a long-term perspective.

Spatial scale frames system interconnections across heterogeneous geographic spaces [3], relating to both intensity of production and heterogeneity among different types of food system actors. For example, subsistence-level food system dynamics reveal very different interconnections and outcomes than a market-based food system. As markets expand from local to regional, national, and international 
markets, interconnections grow, which gives rise to complex interconnections in which policy or climatic disruptions localized in one region can impact prices across the globe. These scales are nested and interconnected with price signals, consumer preferences, policy, and other influences reverberating across scales. Sensitivity to scale allows us to see the forces that give rise to some food system outcomes, such as increasing concentration in the food system, while allowing us to consider scale-appropriate regulations and market development that serves particular production scales [14].

While food systems courses must be inter/trans-disciplinary, our courses use an applied economics lens, a discipline that is essentially rooted in a system force. The market system connects producers, consumers, and other actors in the supply chain, with signals such as price, quality, quantity, and other attributes of food shaping what is produced and what is consumed. In general, markets act as balancing feedback loops because price signals induce balancing changes on the demand and supply sides of a market. Meanwhile, social and cultural movements influence laws and regulations, purchasing decisions, and education. While the hand of the government, consumers, and activists is often quite visible to students of food systems, the "invisible hand" of the market must become visible for students to use systems thinking concepts.

Other frames from applied economics are also applicable. For example, issues of food system sustainability can be framed as market failures, such as externalities (e.g., pollution and market wage below living wage); insufficient provision of public goods (e.g., clean air, water, public spaces); or asymmetric information problems (e.g., price is an insufficient signal to convey information about food quality or attribute) [15]. Public policy or private market interventions aim to alter system outcomes by internalizing the negative externalized costs of production (direct regulation or tax to impact price signals) or providing voluntary/ancillary benefits (labels or certifications to transmit more product information).

\subsubsection{Characteristic Set of Behaviors, Often Classified as Its 'Function' or 'Purpose'}

The primary purpose of the food system is to provide adequate food to each person on the planet for a healthy and active life $[3,16]$. But for humans, food serves social and cultural function beyond caloric and nutrient intake. The complex relationships and forces in the food system produce the intended functions for some but also produce unintended consequences of food insecurity for many due to unequal distribution of power and resources from economic and legal forces, many of which lie outside of the food supply chain [3-5]. Other unintended system consequences such as environmental degradation, food-related illness, and declining rural economies can in turn hinder the ability to reach the intended outcomes of the food system [3-5].

Systems thinking shows how system outcomes—intended and unintended-arise naturally from the interconnections between system elements [17]. We use the analogy of a three-legged table, whose legs are the social, economic, and environmental underpinnings of the food system, which are each vulnerable to system disruptions [3]. For the table to sustainably support the intended purpose of the food system - to provide food security for each person—each of the legs must be structurally sound and balanced to be resilient to short-term shocks or long-term stresses (Figure 2).

A goal of food system studies is to diagnose the causes of food system failures, envision a more sustainable and resilient food system, and design strategies to improve it. The first step to changing a complex system is to understand it: Break the system down into elements, watch how the elements are interconnected and whether the forces connecting the elements are changeable, and observe the outcomes of the system. Although this recipe for systems thinking sounds easy, it is complex with food systems that are comprised of interconnected natural and human processes that are self-organizing, non-linear, and uncertain [13]. Even as we identify leverage points in the system that could improve outcomes, the inherent tradeoffs among the three legs of the table supporting the food system must be considered. For example, if a firm uses environmentally friendly methods and pays living wages to employees, it will make the food more expensive, hindering food access and making it the purview of wealthy (hurting social goals). 


\section{Food System Intended Outcomes}

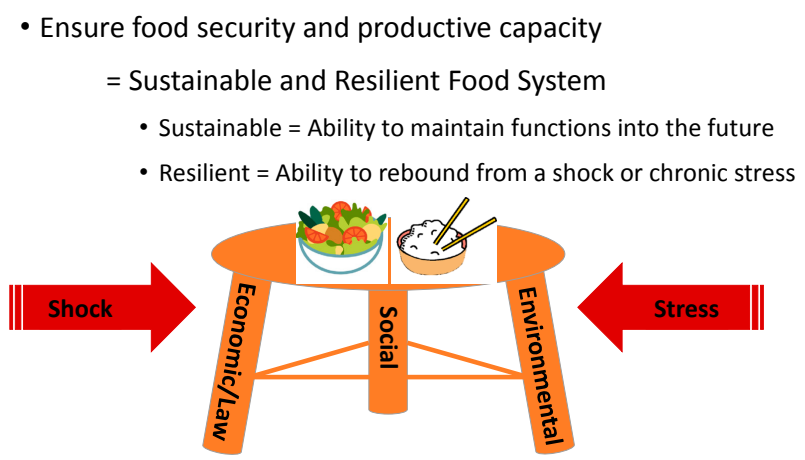

Figure 2. Food system sustainability and resilience diagram used in OSU AGRI 411/511, Introduction to Food Systems, to simply illustrate the foundations of a sustainable and resilient food system.

Students must come to recognize the inherent uncertainty and ambiguity in studying complex systems. There are no "right" answers to food systems problems. Our efforts move the food system in a direction, not to a destination [18]. An implicit structure of food systems courses is "seeking balance" across many environmental, social and economic outcomes [1]. Metrics and indicators help communicate the directional orientation for assessing the state of the food system; for example, measures of food insecurity, access to land rights and credit, gender equality, the yield gap, distribution of income and wealth, wasted food, and soil health can be tracked over time $[3,16]$.

Introducing these concepts is only the first part of the recipe for a food systems course: Food systems courses must not only emphasize the object of inquiry as a system but use learning activities and methods that support interdisciplinary analysis and other implicit program goals $[1,8]$. Appropriate and effective pedagogy gives students experience and practice thinking in systems to use this approach in class and in the future as food systems professionals.

\subsection{How to Teach Systems Thinking: Food System Learning Activities and Implementation}

The signature pedagogy for sustainable food systems programs positions aspects of both what to teach and how to teach it in the surface, deep, and implicit levels of the framework [1]. Here we reorganize the concepts while drawing on other food systems pedagogy literature to identify the types of learning activities and implementation strategies-how to teach-such that students gain systems thinking skills reflecting all levels of the food systems signature pedagogy. Rather than simple retention of facts that can be tested, students acquire methods of analysis and problem solving to put into practice. Furthermore, implementation strategies ensure that "an individual capacity to think and act systematically [is] complemented by the collective capacity through processes of 'social learning'"' [19].

\subsubsection{Learning Activities}

Here we have collected learning activities suited to teaching systems thinking from the food systems education literature. They are gathered into five distinct categories: Deductive Case Studies, Experiential Learning, Reflective Narrative Learning, System Dynamics Simulations and Scenarios, and Inductive/Open-Ended Case Studies, with a description of each in the context of sustainable food systems courses from the literature in Table 1.

Each of these learning activities is a form of active or engaged learning, which engages students in the learning process during time in the classroom or in homework, facilitating foundational knowledge and higher-level skill acquisition [20]. Complex systems thinking, problem solving, and explicit attention to values underlying food systems dynamics require higher cognitive skills which require students to be active agents in the learning process, take risks, and work with others 
collaboratively [21-23]. These five learning activities exemplify engaged learning activities for food systems concepts that combine theory and practice, use different types of reasoning skills, and engage higher-order cognitive skills leading to innovation and creativity in problem solving.

Table 1. Learning Activities for Sustainable Food Systems Courses.

\begin{tabular}{|c|c|}
\hline $\begin{array}{l}\text { Learning } \\
\text { Activities }\end{array}$ & Description \\
\hline $\begin{array}{l}\text { Deductive } \\
\text { Case Studies }\end{array}$ & $\begin{array}{l}\text { "[M]ultiple cases are considered together to form the foundation for addressing a broader food system } \\
\text { challenge or research question ... contrasting case studies in very different systems enhance[s] learning } \\
\text { with a comparison of how different concepts play out in different food systems" [8] (p. 732). }\end{array}$ \\
\hline \multirow{2}{*}{$\begin{array}{l}\text { Experiential } \\
\text { Learning }\end{array}$} & $\begin{array}{l}\text { "Experiential learning...demonstrates that theoretical concepts must be tailored to specific contexts, } \\
\text { enhanced by accepting diverse perspectives as part of the knowledge generation and application } \\
\text { process" [1] (p. 9). }\end{array}$ \\
\hline & $\begin{array}{l}\text { "Experience-based learning can give students direct experience bridging theoretical knowledge and } \\
\text { practical problems" [8] (p. 733), i.e., field trips, service-learning, and applied research opportunities. }\end{array}$ \\
\hline \multirow{4}{*}{$\begin{array}{l}\text { Reflective } \\
\text { Narrative } \\
\text { Learning }\end{array}$} & $\begin{array}{l}\text { "Reflective essays are assignments that require students to reflect on their learning as a personal } \\
\text { experience by connecting their interests, values, and development with other cognitive and affective } \\
\text { dimensions of learning" [10] (p. 51). }\end{array}$ \\
\hline & $\begin{array}{l}\text { "Self-reflection is a process which entails scrutinizing and possibly rejecting the validity of one's own } \\
\text { habitual beliefs ... most of these inquiry processes require students to reflect and explore what is valuable } \\
\text { to them in a subjective way, and then link it to empirical inquiry and reportable results" [22] (p. 134). }\end{array}$ \\
\hline & $\begin{array}{l}\text { "Students...begin their reflective practice by identifying their personal beliefs, values and attitudes built } \\
\text { from prior experiences. Students are then asked to recognize these patterns in others. Further, common } \\
\text { ways of seeing and knowing are discussed to reveal the social, cultural and historical influences on food } \\
\text { system knowledge. This results in continual questioning of processes and outcomes in food system } \\
\text { development" [1] (p. 10). }\end{array}$ \\
\hline & $\begin{array}{l}\text { "Narratives can increase student motivation for learning and engagement with unfamiliar subject areas, } \\
\text { encourage student responsibility as co-creators of knowledge, and contribute to effective leadership } \\
\text { development as stories can help build trust and provide inspiration" [17] (p. 307). }\end{array}$ \\
\hline \multirow{3}{*}{$\begin{array}{l}\text { System } \\
\text { Dynamics } \\
\text { Simulations } \\
\text { and Scenarios }\end{array}$} & $\begin{array}{l}\text { "Simulation models...help students build understanding of key goals, components and their interactions, } \\
\text { and of resulting system behavior over time and/or space. Various software ... facilitate visualization of } \\
\text { complex systems that can include social, economic and agroecological interactions" [17] (p. 308). }\end{array}$ \\
\hline & $\begin{array}{l}\text { "[Scenario Planning] is a process of social learning by which a group can interweave individual } \\
\text { experiences (both real and anticipated) and understandings of social and biophysical dynamics to } \\
\text { "imagine into being" vivid and contrasting scenarios of plausible future conditions" [19] (p. 95). }\end{array}$ \\
\hline & $\begin{array}{l}\text { "[S]cenario-based case study learning, [presents] students [] with an actual or simulated scenario in... } \\
\text { problems related to a food system .... that put learning into context" [8] (p. 732). }\end{array}$ \\
\hline \multirow{3}{*}{$\begin{array}{l}\text { Inductive/ } \\
\text { Open-Ended } \\
\text { Case Studies }\end{array}$} & $\begin{array}{l}\text { “Open-ended cases ... are suited for developing processes of collaboration, incorporate contextual } \\
\text { knowledge when framing questions, [and] identify leverage points within a system. These skills are } \\
\text { essential to developing cognitive flexibility to address uncertainty" [1] (p. 9). }\end{array}$ \\
\hline & $\begin{array}{l}\text { "An inductive case study learning approach....asks students to develop their own narrative or } \\
\text { explanations of the relevant questions or issues for a particular case ... [for which] problems have not } \\
\text { already been solved, and outcomes or right answers have not been predetermined by the } \\
\text { instructor" [8] (p. 732). }\end{array}$ \\
\hline & $\begin{array}{l}\text { "Design thinking (DT) is typically practiced via a sequence of activities termed empathizing, problem } \\
\text { identification, idea formulation, prototyping and testing. Particularly when practiced by a group, } \\
\text { the initial stages of DT are intrinsically systemic ..." [17] (p. 308). }\end{array}$ \\
\hline
\end{tabular}

\subsubsection{Implementation Strategies}

Throughout the literature and the descriptions of these five learning activities is an emphasis on group interaction, inter/trans-disciplinarity, and instructor-modeled co-learning throughout the learning activities. These strategies, summarized in Table 2, facilitate the deep and implicit structure of a food system signature pedagogy and can be practiced across topics and learning activities [1]. 
Table 2. Implementation Strategies for Food System Course Learning Activities.

\begin{tabular}{|c|c|}
\hline Implementation & Description \\
\hline \multirow[b]{2}{*}{$\begin{array}{l}\text { Collaborative Group } \\
\text { Learning }\end{array}$} & $\begin{array}{l}\text { "Having students participate in a collective response to global pressures models the growing } \\
\text { nature of professional culture in the food system" [1] (p. 10). }\end{array}$ \\
\hline & $\begin{array}{l}\text { "The complementarity of approaches, experiences, and knowledge bases of a group of students } \\
\text { can encourage multi-dimensional and creative thinking around food systems problem solving.... } \\
\text { the group learning approach allows students to engage with the case in a much deeper way than } \\
\text { each would have been able to individually" [8] (p. 735). }\end{array}$ \\
\hline \multirow{3}{*}{$\begin{array}{l}\text { Inter/ } \\
\text { Trans-Disciplinarity }\end{array}$} & $\begin{array}{l}\text { "intentionally integrates the natural and social science dimensions of the food system to inform } \\
\text { the study of production, distribution and consumption ... intentionally build on the experiential } \\
\text { learning components of their curriculum to push inter- and multi-disciplinary strategies further to } \\
\text { a transdisciplinary approach, incorporating humanistic and non-academic ways of knowing into } \\
\text { course curriculum" [1] (p. 6). }\end{array}$ \\
\hline & $\begin{array}{l}\text { "Food systems are inherently connected to the domains of multiple disciplines, and, as such, their } \\
\text { study requires an interdisciplinary approach. Interdisciplinary education engages multiple } \\
\text { perspectives through both theory and method" [8] (pp. 725-726). }\end{array}$ \\
\hline & $\begin{array}{l}\text { "The challenges of sustainable food systems [] necessitate finding ways to generate more creative } \\
\text { collaborative friction between the social and the natural sciences .... Incorporating knowledge } \\
\text { and concerns of non-academic stakeholders is another way [to] improve understanding of the } \\
\text { food system and create possibilities for change" [18] (pp. 29-30). }\end{array}$ \\
\hline \multirow{3}{*}{$\begin{array}{l}\text { Instructor-Modeled } \\
\text { Co-Learning }\end{array}$} & $\begin{array}{l}\text { Instructors creating better learning experiences engage in: "supporting students' reflection } \\
\text { processes, creating safe spaces for dialogues about positionality and social location, preparing } \\
\text { students for non-hierarchical views of knowledge and promoting discordant pluralism" [1] (p. 11) }\end{array}$ \\
\hline & $\begin{array}{l}\text { "Creating a safe space for deliberations of deeply important matters allows for engagement } \\
\text { without domination that coerces conversion ..." [10] (p. 46). }\end{array}$ \\
\hline & $\begin{array}{l}\text { Cooperative group learning also allows instructors to behave as facilitators of knowledge rather } \\
\text { than holders of knowledge" [8] (p. 735). }\end{array}$ \\
\hline
\end{tabular}

Collaborative group work is a key strategy for implementing the learning activities: "the complementarity of approaches, experiences, and knowledge bases of a group of students can encourage multi-dimensional and creative thinking around food systems problem solving ... in a much deeper way than each would have been able to individually" [8]. Studying food systems is necessarily an inter/trans-disciplinary endeavor, which is enhanced by group work and integrated into systems thinking $[1,8,18]$. While many sustainable food systems programs grew out of sustainable agriculture studies, other disciplines such as economics, law, sociology, anthropology, philosophy, history, engineering, and many others intersect in food systems. While applied economics is a useful lens for organizing food systems inquiries, it cannot be the exclusive lens and explicit attention must be paid to other ways of knowing and evaluating food systems dynamics and outcomes.

Another insight from the literature is the importance of opportunities for the instructor to explicitly teach and model how to approach complex problems for analysis, propose solutions, and work collaboratively in groups, which we call instructor-modeled co-learning [20]. Many of the learning activities inherently foster engagement in non-hierarchical, responsive, reflective, and flexible learning environments that are safe spaces for discordant pluralism, in which the knowledge flows both ways between students and instructors $[1,10,21]$. Within the learning activities, students can be explicitly reminded about the open nature of the inquiry and invited to ask more questions of the material, the instructor, other experts, and each other. More than choosing learning activities that open up space for co-learning among students, the crux is a pedagogical, philosophical, and personal commitment on the part of the instructor to consciously remain humble, remain a learner, and model that approach to the students [13]. It is powerful when an instructor can say, "I had not considered that perspective," "I learned something new today," or "I don't know but I will find out" to the class, then to model how the new perspective informed a conclusion, or follow through by bringing new information. Co-learning allows instructors to behave as "facilitators of knowledge rather than holders of knowledge", empowering students to be co-creators of knowledge [8]. 


\subsection{Samples of the Food System Courses: Combining What and How to Teach in Theory and Practice}

To analyze whether and how we are incorporating the recommended learning activities and implementation strategies in our courses, we categorized assignments that we use in our courses at OSU, UMN, and UVM (Appendix A). Taken together, we have examples of three to five learning activities in each category; some assignments are used at more than one university. Here we will discuss examples of how each learning activity is implemented to achieve the deep and implicit goals of a food systems course.

\subsubsection{Deductive Case Studies}

A foundational cognitive skill for systems thinking is to look at multiple examples or cases and deduce systems-level conclusions about common actors, system forces, and outcomes. Deductive case studies are also useful for contrasting and explaining different outcomes in different settings. Considering many cases allows a level of abstraction from the minutia of individual problems to broader implications. In the UVM course, students select and present recent articles from the news, then draw conclusions about market failures at work and propose policy or market solutions to address the issues presented. Pioneered at the UMN and now also used in the OSU course, a State-Level Food System Indicators assignment tasks students to compare economic, environmental, health, and social indicators (e.g., value of agricultural sales, percent of farmland enrolled in conservation programs, percent population overweight, percent of population receiving SNAP benefits) in different states or across different time periods. Through comparisons, students gain skills in systems thinking by considering the various actors, resources, and forces present in each state to produce different (or similar) food system outcomes.

Deductive case studies give students practice at seeing examples from the real-world and abstracting from the specific situation to the systems-level forces at work. They can be done individually but are particularly powerful when then combined into group learning so that students can share and debate their conclusions. While there may be some "right" and "wrong" answers, they can be discovered through collaborative and open discussion that illuminates different perspectives and analyses. Instructors and students can practice co-learning based on their different experiences.

\subsubsection{Experiential Learning}

Experiential learning is key in a full food systems degree or certificate program but difficult to realize in a single food systems course. The explicit interdisciplinary design of the OSU and UMN food systems class is in part realized through a heavy reliance on guest speakers from within and outside of campus, bringing experiences to students in the classroom. For example, an agroecology professor lectures on the water quality impact of current field cropping systems, and a nutrition professor discusses individual food choice factors and policy interventions. Outside practitioners bring real-world experience, such as local dairy partners who are preparing to expand to bring back the next generation, local food bank staff, and a former General Mills executive who led their sustainability initiatives. Interactive in-class experiences are particularly compelling, such as a visit by a processed-food manufacturer that invited OSU dining services to class to have an open discussion about how they can get their products sold in campus stores, and student participation in a taste test and marketing study to demonstrate market research studies. At UMN, a Lakota Sioux chef spoke about cultural traditions and historical changes in native foodways and served Native American foods to students. For OSU's Ecampus section, students have "virtual" field trips with videos created specifically for the class, with visits to the OSU dairy, plant breeding and genetic engineering labs, and others.

While guest lectures may be a weak form of experiential learning, they can capture the goals of experiential learning if developed in intentional collaboration with the speakers; in the reflection papers and course evaluations, some of the outside speakers are often mentioned as impactful learning 
opportunities. Guest speakers also create an opportunity for instructor-modeled co-learning: Students are often reluctant to challenge assumptions or ask questions of a guest speaker, but the instructor can model engagement through questions or comments that relate specifically to class themes. After hearing from several different speakers, instructors can also reference the presentations in relation to one another (or ask students to do so through reflection papers), to understand the interconnectedness of the food supply chain. For example, at OSU the speakers on food production topics often talk about consumer demand or marketing, and the speakers on the processing or marketing topics often talk about production methods related to food labeling. While revisiting food systems concepts, the instructor can explicitly point out these observations about the interconnectedness of the supply chain to demonstrate systems thinking skills.

Experiential learning can also occur through hands-on research that culminates in a project deliverable that engages the class. At UMN, students work in groups to create a 45 to 50 min workshop built via systems thinking concepts. The workshop must be designed to maximize engagement with peers; some student work has been immensely creative. For example, in one activity, students needed to figure out how to feed "your family" with a monthly budget augmented by SNAP benefits, and in another, the task was to complete a food shopping mission starting from a food desert. The design of this group project engages systems thinking and experiential learning in both the presenters who must create the workshop and for the learners who participate due to the explicit focus on hands-on engagement.

\subsubsection{Reflective Narrative Learning}

Student learning is enhanced "when learning and teaching methodologies prompt faculty and student reflection and deliberation upon the multiple values that influence and shape" sustainable food systems [10]. At OSU, one technique for incorporating reflective narrative approaches is a periodic short reflection paper that asks students to relate the class material to their disciplinary and personal experience and values, which is also an opportunity to engage in inter/trans-disciplinary thinking. Emphasis is placed on generating more questions that arise from the materials, explicitly reminding the students to keep an open, reflective, "stay humble, stay a learner" systems thinking mindset. Some reflection papers relate to the process of learning, such as: Have you heard perspectives that you have not heard before? What have you learned about communicating across perspectives and disciplines? At UMN, students do short in-class reflections after viewing content on contrasting perspectives, such as historical perspectives from Native Americans and European settlers.

Another discussion incorporated into the OSU course invites students and the instructor to share a "food story" from their own life-such as a cultural connection practiced through food traditions, experiences with food assistance programs, or work experience in the food system. Sharing food stories is a way to build community and to see that there are many experiences that we share, or that we could learn from. It requires some risk taking, but when some people share an experience, others often speak up about similar experiences. Later in the class, when potentially polarizing food systems topics arise, such as food assistance programs or low wage labor, we can recognize that people in the room have lived experience with the topic because we have already shared it in a safe space. Sharing stories concretizes the concept that different people have different past, current and potentially future interactions in the food system. Recognizing that sharing personal experiences can be emotionally risky, sharing food stories only happens after a few weeks of class, and the instructor is a full participant, sharing personal food stories as a model and to build relationships.

\subsubsection{System Dynamics Simulations and Scenarios}

Food systems scholars have developed a broad array of system dynamic simulation, scenario, and modeling approaches that incorporate physical sciences and socio-economic factors for an integrated approach to understanding issues ranging from food waste, land use, climate change, market integration, and others [2,24-27]. Given that our food systems classes are interdisciplinary 
and cover a broad range of material, we can introduce our students to this literature to demonstrate approaches and findings. However, we assign simple system dynamic simulations and scenario learning activities to illustrate and practice essential system thinking concepts, such as system elements and feedback loops. Food system diagrams and causal loop diagrams $[13,28,29]$ are simple and effective ways to engage students with system dynamics concepts. To introduce the idea of a food system, students in the OSU class draw a simple food system diagram of their choice (vary by scale or place) in the first week of class, then revisit it at the end of the class to add refinements and dynamics gained through their studies. A causal loop diagram focuses on interconnections and forces in the food system; students demonstrate types of feedback loops that arise from the physical, economic, or social relationships between food system elements. At UMN, VENSIM (a system dynamics modeling software package with a no-cost student version) has been used to build a human population model and a crop-weed system model of how herbicide-resistant weeds develop over a 30 year period.

A scenario activity is used at UMN, which asks students to choose a key driver for change in the U.S. food system, then describe an "alternative history" to imagine how the food system could have evolved differently via the driving force under different conditions. These system dynamic simulations and scenarios are useful to make abstract forces that play out over long time periods more concrete, which aids in understanding system dynamics and long-term outcomes.

\subsubsection{Inductive/Open-Ended Problem-Oriented Case Study}

In the OSU course, a policy brief assignment is developed over the course of the quarter as a problem-oriented, open-ended case study of one adverse food system outcome. It is implemented as collaborative group work, along the lines of a design thinking learning activity [17]. Students first individually propose three topics to address, then the instructor assigns groups based on interests and interdisciplinarity to make learning experiences most meaningful [22]. The first two assignments require each student to submit an individual paper on the group topic: A problem statement researching the system elements and forces that give rise to the problem, then a policy formulation that recommends a policy to address the problem, discussing the leverage points that create change and any anticipated but unintended consequences of the policy. Students share and peer review these independent assignments within the group, then collaborate to create a single policy brief and presentation for the rest of the class. Groups also have at least one meeting with the instructor, which is a forum for explaining the system thinking process embedded in the design of the assignment in the context of the chosen topic. In practice, students often start with an idea of a policy change, rather than starting with a problem to study; i.e., they come with "a solution in search of a problem" (common themes are eliminating federal farm subsidies or banning high-fructose corn syrup). The design of the assignments and meetings reinforce the systems thinking process.

Students must take an interdisciplinary and collaborative approach due to the project design, keeping an open mind to different information and perspectives to deal with the inherent uncertainty in food system dynamics and outcomes. The instructor must also stay open to student perspectives and reasoning, focusing on the process and providing a roadmap to gathering and using information, rather than steering students toward a preconceived policy recommendation. Students have produced creative and unexpected policy recommendations through their collaborations; others have taken tough questions from classmates when their information was incomplete or analyzed in a simplistic way. Leaving students free to create their own recommendations opens the door for authentic critical analysis of self and others. At the UMN and UVM, similar open-ended case studies are used. The topic is fixed for the class, but small groups work on different aspects of the problem. At the UMN, topics have included food waste and food deserts. At UVM, student engaged in a case study of a hospital's local food procurement. 


\section{Discussion: Opportunities and Challenges for Creating a Nourishing Food Systems Course}

The food systems pedagogy literature goes beyond the mechanics of learning activities and implementation strategies to the broader goals of a food systems curriculum. Teaching foundational courses in our universities' food systems programs, we can lay a groundwork for students that will carry through their studies, but we also have one chance to reach some students who are only taking the food systems class to meet a graduation requirement or to fulfill a personal interest. Our students come from diverse experiences and perspectives-from the committed vegan to the next generation rancher. Food systems work engages all of us-as eaters, consumers and citizens-and more deeply engages those that will go to work in the food system-as farmers, ranchers, food business entrepreneurs, marketers, advocates, or policy makers. In every future role, the stretch goals of a food systems course prepare students for a future improving the food system by "supporting students' reflection processes, creating safe spaces for dialogues about positionality and social location, preparing students for non-hierarchical views of knowledge and promoting discordant pluralism" [1]. Reaching these stretch goals in food systems courses requires courage and skill on the part of the instructor to become a facilitator and a model, rather than an authoritarian enforcer of classroom behavior and conclusions. Although explicit discussion of values feels risky or inappropriate in science-based disciplines, to ignore or pretend that values do not shape food systems outcomes is intellectually dishonest; we must be prepared to engage values in both what we teach and how we teach it. "It can be paralyzing to seriously consider the question: Is the way I teach a true reflection of my values, and does it serve my ultimate goals for this class, society, my students, and myself? But posing these kinds of questions can also provide liberation from rote tradition if it encourages sympathetic self-reflection that spurs changes in practice" [10].

The first step in liberating a course from rote tradition is to choose learning activities that lend themselves to systems thinking concepts, self-reflection, and angles for exploring values. The next step is to implement the activities using the strategies that put students in contact with other disciplines and perspectives, particularly with those that arise in the classroom with a commitment to instructor-modeled co-learning. It takes conscious effort and practice in every class period to model and maintain the ground rules of civil discordant pluralism and to be explicit about our goals-to explore, learn, and grow both our knowledge and our skills, understanding that there is no one "right" answer to food systems problems, but a constant process of moving forward toward goals that we carefully balance, aware of the inherent tradeoffs. We will not always agree on the evaluation of the tradeoffs; respectful disagreement is a positive outcome in a food systems course.

Teaching food systems from an applied economics perspective could cultivate an open dialog about values, if we intentionally create space. When defining "negative externalities", we can make explicit the question of "negative for whom?" and "who benefits by externalizing costs and why are they able to do so?". We can pay attention to the distributional issues of changes in social welfare by explicitly considering who benefits and who bears the cost of the action. Doing so helps to explain some of the consequences of policy proposals by analyzing systems of power and oppression, institutional and structural pathways for change, and personal and social values. Explicit consideration of values can also be modeled by the instructor, inviting discussion of similarities and differences to move away from an "either/or" choice to a "both/and" appreciation of divergent views. We can draw on a robust academic tradition of civil argument, in which the emotional tenor of the engagement is one of lively debate in a community of learners [1,10].

Our experiences developing and teaching food systems courses resonate with others in the sustainable agriculture and food systems literature: To change the food system, we have to change the way we teach students "to facilitate their transformation into active knowledge producers, engaged citizens, and democratic members of our global community" [22]. There are substantial personal and institutional barriers to implementing transformational teaching experiences. Students often expect the passive lecture-exam paradigm, resisting transformational learning activities. Instructors are challenged by these student expectations and our own lived experience as students in the traditional 
model. Other faculty also continue to replicate traditional passive learning models, leading us to feel alone in facilitating transformational learning experiences [22]. Universities are beginning to recognize the importance of active learning activities, but we often lack mechanisms to allow for extra time or infrastructure for active learning course designs (i.e., recognition in faculty course load, assignment of teaching assistants, use of innovative classroom environments, compensation for guest speakers, recognition in evaluation processes). As transformational learning begins to permeate the university teaching system, we can be advocates for educational transformation that equips students to in turn transform the food system.

\section{Conclusions}

Responding to the call from Valley et al. [1] to make available more examples of pedagogical transformations from food systems courses to identify successful practices and potential challenges, we boiled down the food system curriculum literature and offer a concentrated look at food systems courses across our three universities, offering concrete tools and inspiration to instructors across the food systems curriculum. We also recognize that our food systems courses are the only taste of the complex problems that some students experience in their university careers-they may not opt for a full degree program, certificate, minor, or concentration in a food systems field, but they may opt for this one course. Even with just a taste, we can impact a wide range of students in a variety of disciplines, equipping them with awareness and tools about food systems as professionals, advocates, and citizens $[1,3,8,17,22]$.

By collaborating within and between our universities, we can practice what we preach to give rise to communities of practice that change cultural and institutional norms and rules within the university teaching system. Students will come to expect more from their education than a lecture followed by an exam, and will come to expect more of themselves as they enter a world of wicked problems in the food system in any role that they play, from consumer to policy maker.

Author Contributions: C.A.B. reviewed the literature and constructed the analytical framework; C.A.B., H.H.P., R.P.K., and D.C. gathered and analyzed the data from course materials; C.A.B., H.H.P., R.K., and D.C. wrote the paper.

Funding: This study and publication costs were funded by the U.S. Department of Agriculture under National Institute for Food and Agriculture grant 2014-68006-21854.

Acknowledgments: Many thanks to our fellow teachers, especially those involved in early development of our courses, such as Lauren Gwin (OSU) and Will Secor (UMN). We are also grateful to our students for engaging and inspiring us in each class. We also thank two anonymous reviewers for thoughtful comments and critiques that strengthened the structure and organization of the manuscript.

Conflicts of Interest: The authors declare no conflict of interest. The founding sponsors had no role in the design of the study; in the collection, analyses, or interpretation of data; in the writing of the manuscript, and in the decision to publish the results. 


\section{Appendix A. OSU, UMN, UVM Food Systems Course Learning Activities}

\begin{tabular}{|c|c|c|c|c|}
\hline $\begin{array}{l}\text { Learning } \\
\text { Activity }\end{array}$ & $\begin{array}{l}\text { University } \\
\text { Course }\end{array}$ & Assignment & $\begin{array}{l}\text { Implementation } \\
\text { Strategies }\end{array}$ & Description \\
\hline \multirow{3}{*}{$\begin{array}{c}\text { Deductive Case } \\
\text { Studies }\end{array}$} & UMN/OSU & $\begin{array}{l}\text { State-Level } \\
\text { Food System } \\
\text { Indicators }\end{array}$ & $\begin{array}{l}\text { Inter/Trans- } \\
\text { Disciplinarity }\end{array}$ & $\begin{array}{l}\text { Students are introduced to the University of Minnesota } \\
\text { State Level Food System Indicators (https:/ / www.hfhl. } \\
\text { umn.edu/research/food-system-indicators) for their } \\
\text { "home" state. Then each student is assigned another } \\
\text { state and asked to identify and explain key differences } \\
\text { and similarities for indicators in } 2012 \text { and for trends in } \\
\text { indicators from } 1997 \text { to } 2012 \text {. }\end{array}$ \\
\hline & OSU & $\begin{array}{c}\text { Retail Analysis } \\
\text { Project }\end{array}$ & $\begin{array}{l}\text { Collaborative } \\
\text { Group } \\
\text { Learning }\end{array}$ & $\begin{array}{l}\text { Students gather information on price and product } \\
\text { attributes for food items available for sale in different } \\
\text { retail environments. They enter the data into a shared } \\
\text { class spreadsheet, then analyze overall trends in the } \\
\text { class-created database by type of retail environment, } \\
\text { price, quantity, quality, product attributes, etc., to draw } \\
\text { conclusions about food marketing strategies. }\end{array}$ \\
\hline & UVM & $\begin{array}{l}\text { Market Failure } \\
\text { and Policy } \\
\text { Concept } \\
\text { Application }\end{array}$ & $\begin{array}{l}\text { Instructor- } \\
\text { Modeled } \\
\text { Co-Learning }\end{array}$ & $\begin{array}{l}\text { Students select, assign, and present recent articles from } \\
\text { the popular press which highlight one or more of the } \\
\text { pertinent concepts from class (e.g., market failures) and } \\
\text { propose policy and/or market solutions to address } \\
\text { the issues. }\end{array}$ \\
\hline \multirow{4}{*}{$\begin{array}{l}\text { Experiential } \\
\text { Learning }\end{array}$} & OSU & $\begin{array}{c}\text { Guest } \\
\text { Speakers/Virtual } \\
\text { Field Trips }\end{array}$ & $\begin{array}{l}\text { Inter/Trans- } \\
\text { Disciplinarity. } \\
\text { Instructor- } \\
\text { Modeled } \\
\text { Co-Learning }\end{array}$ & $\begin{array}{l}\text { The on-campus section invites guest speakers each week } \\
\text { that range from OSU professors on plant breeding, food } \\
\text { safety, and human health, to outside professionals such } \\
\text { as a local organic dairy farmer, a packaged food } \\
\text { business, and food assistance program professionals. } \\
\text { Activities range from lecture to role playing activities, } \\
\text { depending on the speaker. In the online Ecampus } \\
\text { section, video interviews of experts were recorded at } \\
\text { locations such as the OSU organic farm, dairy, } \\
\text { and cheese making laboratory to create virtual field trips } \\
\text { and engage with class themes. }\end{array}$ \\
\hline & OSU & Food Diary & $\begin{array}{c}\text { Inter/Trans- } \\
\text { Disciplinarity }\end{array}$ & $\begin{array}{l}\text { Before the class on individual food choice drivers, } \\
\text { students are asked to keep a food diary of what they eat, } \\
\text { when, with whom, etc., to apply the food choice factors } \\
\text { from the research during the guest lecture. }\end{array}$ \\
\hline & UMN & $\begin{array}{c}\text { Guest } \\
\text { Speaker-Sioux } \\
\text { Chef }\end{array}$ & $\begin{array}{l}\text { Inter/Trans- } \\
\text { Disciplinarity }\end{array}$ & $\begin{array}{l}\text { Sean Sherman, a Lakota Sioux and recent James Beard } \\
\text { Award winner, led a class session in which he spoke and } \\
\text { served Native American foods to students as part of the } \\
\text { food system history segment of the course. Students } \\
\text { prepared for the session by reading an ethnographic } \\
\text { account of the "food year" for either the Dakota Sioux or } \\
\text { the Ojibwe. }\end{array}$ \\
\hline & UMN & $\begin{array}{l}\text { Student-led } \\
\text { workshops }\end{array}$ & $\begin{array}{l}\text { Collaborative } \\
\text { Group } \\
\text { Learning, } \\
\text { Inter/Trans- } \\
\text { Disciplinarity, } \\
\text { Instructor- } \\
\text { Modeled } \\
\text { Co-Learning }\end{array}$ & $\begin{array}{l}\text { Students research and offer a } 45-50 \text { min workshop to the } \\
\text { class on their identified topic. To prepare the workshop, } \\
\text { students conducted research in groups on the topics } \\
\text { respectively assigned. The objective of the workshop } \\
\text { was to (a) provide background information on the issue, } \\
\text { (b) present behavior of } 3 \text { to } 5 \text { key factors over time, } \\
\text { and (c) introduce stakeholders related to the issue and } \\
\text { their goals. They also prepared a handout and a draft } \\
\text { causal loop diagram based on their understanding of the } \\
\text { topic. The students were to design the workshop in } \\
\text { a way to maximize engagement and learning amongst } \\
\text { their peers. The topics ranged from food assistance } \\
\text { programs, farm labor and immigration policies, to } \\
\text { environmental impacts of fertilizer use. }\end{array}$ \\
\hline
\end{tabular}




\begin{tabular}{|c|c|c|c|c|}
\hline \multirow{4}{*}{$\begin{array}{l}\text { Reflective } \\
\text { Narrative } \\
\text { Learning }\end{array}$} & OSU & $\begin{array}{l}\text { Reflection } \\
\text { Papers }\end{array}$ & $\begin{array}{l}\text { Inter/Trans- } \\
\text { Disciplinarity, } \\
\text { Instructor- } \\
\text { Modeled } \\
\text { Co-Learning }\end{array}$ & $\begin{array}{l}\text { Reflection papers cover the material for } 2 \text { or more weeks } \\
\text { of class, asking students to relate the class material to } \\
\text { their disciplinary and personal experience and identify } \\
\text { food systems themes. Emphasis is placed on generating } \\
\text { more questions that arose from the materials. Some } \\
\text { reflection papers relate to the process of learning, such } \\
\text { as: Have you heard perspectives that you have not } \\
\text { heard before? What have you learned about } \\
\text { communicating across perspectives and disciplines? }\end{array}$ \\
\hline & OSU & Food Stories & $\begin{array}{l}\text { Instructor- } \\
\text { Modeled } \\
\text { Co-Learning }\end{array}$ & $\begin{array}{l}\text { Students and the instructor share a "food story" from } \\
\text { their own life-how food connects you to family or } \\
\text { culture, experience working with food, a food } \\
\text { experience from international travel, or a health } \\
\text { connection that food has played a part in. Sharing food } \\
\text { stories builds familiarity and trust, and to see that there } \\
\text { are many experiences that we share, or that we could } \\
\text { learn from. Discussion is encouraged. }\end{array}$ \\
\hline & $\mathrm{UMN}$ & $\begin{array}{l}\text { In-class } \\
\text { reflections }\end{array}$ & $\begin{array}{c}\text { Inter/Trans- } \\
\text { Disciplinarity }\end{array}$ & $\begin{array}{l}\text { Students are presented with contrasting perspectives } \\
\text { and asked to reflect on how they related to the } \\
\text { perspectives. For example, video clips contrasted } \\
\text { viewpoints of conventional farmers and food ethic } \\
\text { advocates or those of Native Americans and } \\
\text { European settlers. }\end{array}$ \\
\hline & UVM & $\begin{array}{l}\text { Intensive } \\
\text { Discussion }\end{array}$ & $\begin{array}{l}\text { Instructor- } \\
\text { Modeled } \\
\text { Co-Learning }\end{array}$ & $\begin{array}{l}\text { Students "free write" then discuss ways in which Farm } \\
\text { to School programs help achieve National School Lunch } \\
\text { Program goals (childhood nutrition and farm viability), } \\
\text { including how supply chains actors manage asymmetric } \\
\text { information, transaction costs, and inherent tradeoffs. }\end{array}$ \\
\hline \multirow{5}{*}{$\begin{array}{l}\text { System Dynamics } \\
\text { Simulations and } \\
\text { Scenarios }\end{array}$} & UMN/OSU & $\begin{array}{l}\text { Causal Loop } \\
\text { Diagrams }\end{array}$ & $\begin{array}{c}\text { Inter/Trans- } \\
\text { Disciplinarity }\end{array}$ & $\begin{array}{l}\text { Students are given a causal loop diagram of climate } \\
\text { change, food demand, population change, land in } \\
\text { cultivation, etc., and must analyze the interconnections, } \\
\text { type of feedback loops, and integrate other factors into } \\
\text { the diagram to explain climate change drivers and } \\
\text { impacts in the food system. }\end{array}$ \\
\hline & OSU & $\begin{array}{l}\text { Food Systems } \\
\text { Diagram }\end{array}$ & $\begin{array}{l}\text { Inter/Trans- } \\
\text { Disciplinarity, } \\
\text { Instructor- } \\
\text { Modeled } \\
\text { Co-Learning }\end{array}$ & $\begin{array}{l}\text { In the first week of the course, students create a "system } \\
\text { diagram" for any portion of the food system they choose. } \\
\text { They discuss and respond to one another and the } \\
\text { instructor. At the end of the course they revisit the } \\
\text { diagram made at the beginning to make adjustments } \\
\text { based on what they learned. }\end{array}$ \\
\hline & UMN & $\begin{array}{l}\text { Modeling } \\
\text { Population } \\
\text { Dynamics }\end{array}$ & $\begin{array}{c}\text { Inter/Trans- } \\
\text { Disciplinarity }\end{array}$ & $\begin{array}{l}\text { Students build a simple human population model as } \\
\text { an introduction to VENSIM, a system dynamics } \\
\text { modeling software package with a student version that } \\
\text { can be downloaded at no cost. }\end{array}$ \\
\hline & $\mathrm{UMN}$ & $\begin{array}{l}\text { Modeling } \\
\text { Herbicide } \\
\text { Resistance }\end{array}$ & $\begin{array}{l}\text { Inter/Trans- } \\
\text { Disciplinarity }\end{array}$ & $\begin{array}{l}\text { Students are given a simple flow diagram for } \\
\text { a crop-weed system that initially includes a very small } \\
\text { number of herbicide resistant weeds. They develop } \\
\text { a VENSIM model to trace the shift in the weed } \\
\text { population to the herbicide resistant strain over } \\
\text { a 30-year period. }\end{array}$ \\
\hline & $\mathrm{UMN}$ & $\begin{array}{l}\text { Food System } \\
\text { History }\end{array}$ & $\begin{array}{l}\text { Inter/Trans- } \\
\text { Disciplinarity }\end{array}$ & $\begin{array}{l}\text { Each student chooses a key driver for change in the U.S. } \\
\text { food system that was the basis for fundamental, } \\
\text { far-reaching change. The student then describes } \\
\text { an "alternative history" for the driving force and traces } \\
\text { out how the food system could have evolved differently. } \\
\text { The paper includes a discussion of the economic, social, } \\
\text { and environmental implications of the alternative future. }\end{array}$ \\
\hline
\end{tabular}




\begin{tabular}{|c|c|c|c|c|}
\hline \multirow{4}{*}{$\begin{array}{l}\text { Inductive/ } \\
\text { Open-Ended } \\
\text { Case Studies }\end{array}$} & OSU & Policy Brief & $\begin{array}{l}\text { Collaborative } \\
\text { Group } \\
\text { Learning, } \\
\text { Inter/Trans- } \\
\text { Disciplinarity, } \\
\text { Instructor- } \\
\text { Modeled } \\
\text { Co-Learning }\end{array}$ & $\begin{array}{l}\text { Students work in small groups to write and present } \\
\text { an evidence-based policy brief to propose a policy } \\
\text { addressing a current food system problem. The project is } \\
\text { done as multi-step assignment in which they identify } \\
\text { topics of interest to them, are assigned to } \\
\text { interdisciplinary groups (as much as possible, then write } \\
\text { individual papers to identify the actors and forces that } \\
\text { give rise to the problem, propose a policy solution and } \\
\text { analyze unintended consequences and tradeoffs. They } \\
\text { then peer review papers by their group members and } \\
\text { collaborate to combine their information and } \\
\text { perspectives into a final policy paper and presentation } \\
\text { for the class, in which they must field questions. }\end{array}$ \\
\hline & OSU & $\begin{array}{l}\text { Science, } \\
\text { Technology, } \\
\text { and Society } \\
\text { Paper }\end{array}$ & $\begin{array}{c}\text { Inter/Trans- } \\
\text { Disciplinarity }\end{array}$ & $\begin{array}{l}\text { Students choose a food then describe historical } \\
\text { production practices and how change in science and } \\
\text { technology have changed production over time, and in } \\
\text { turn how those changes have affected the economics of } \\
\text { the food product (price/quality/quantity), consumer } \\
\text { acceptance (values/marketing) or regulation of the food } \\
\text { product (law). Then they predict current/future } \\
\text { challenges related to production and evaluate the } \\
\text { possibility of overcoming current } \\
\text { production constraints. }\end{array}$ \\
\hline & UMN & $\begin{array}{l}\text { Food System } \\
\text { Problem Term } \\
\text { Project }\end{array}$ & $\begin{array}{l}\text { Collaborative } \\
\text { Group } \\
\text { Learning, } \\
\text { Inter/Trans- } \\
\text { Disciplinarity, } \\
\text { Instructor- } \\
\text { Modeled } \\
\text { Co-Learning }\end{array}$ & $\begin{array}{l}\text { Students are assigned to groups of three to work on } \\
\text { a unique instance of a "wicked problem" in the food } \\
\text { system. There is one class focus, examples from past } \\
\text { years include food waste and food deserts. Groups work } \\
\text { through a series of assignments. The first focuses on } \\
\text { analysis-description of key elements and } \\
\text { interconnections in the system. The second focuses on } \\
\text { management-identification of the decisions made by } \\
\text { key private and public sector actors in the system and } \\
\text { descriptions of the externalities these decision processes } \\
\text { create. The third focuses on design—proposal of } \\
\text { changes in system structure that will lead to improved } \\
\text { system performance. }\end{array}$ \\
\hline & UVM & $\begin{array}{l}\text { Institutional } \\
\text { Food Service } \\
\text { Case Study }\end{array}$ & $\begin{array}{l}\text { Instructor- } \\
\text { Modeled } \\
\text { Co-Learning }\end{array}$ & $\begin{array}{l}\text { Class examines an in-depth case study of a local } \\
\text { hospital's food local food procurement, including } \\
\text { economic impact, and perceived benefits of vendors and } \\
\text { consumers. }\end{array}$ \\
\hline
\end{tabular}

\section{References}

1. Valley, W.; Wittman, H.; Jordan, N.; Ahmed, S.; Galt, R. An emerging signature pedagogy for sustainable food systems education. Renew. Agric. Food Syst. 2017, 2, 1-14. [CrossRef]

2. Puma, M.J.; Bose, S.; Chon, S.Y.; Cook, B.I. Assessing the evolving fragility of the global food system. Environ. Res. Lett. 2015, 10, 1-14. [CrossRef]

3. Misselhorn, A.; Aggarwal, P.K.; Ericksen, P.; Gregory, P.; Horn-Phathanothai, L.; Ingram, J.; Wiebe, K. A vision for attaining food security. Environ. Sustain. 2012, 4, 7-17. [CrossRef]

4. Foley, J.; Ramankutty, N.; Brauman, K.; Cassidy, E.; Gerber, J.; Johnston, M.; Mueller, N.; O'Connell, C.; Ray, D.; West, P.; et al. Solutions for a cultivated planet. Nature 2011, 478, 337-342. [CrossRef] [PubMed]

5. Godfray, H.C.J.; Beddington, J.R.; Crute, I.R.; Haddad, L.; Lawrence, D.; Muir, J.F.; Pretty, J.; Robinson, S.; Thomas, S.M.; Toulmin, C. Food security. The challenge of feeding 9 billion people. Science 2010, 327, 812-818. [CrossRef] [PubMed]

6. Ericksen, P.J. What is the vulnerability of a food system to global environmental change? Ecol. Soc. 2008, 13, 14-31. [CrossRef]

7. LaCharite, K. Re-visioning agriculture in higher education: The role of campus agriculture initiatives in sustainability education. Agric. Hum. Values 2016, 33, 521-535. [CrossRef] 
8. Hilimire, K.; Gillon, S.; McLaughlin, B.C.; Dowd-Uribe, B.; Monsen, K.L. Food for thought: Developing curricula for sustainable food systems education programs. Agroecol. Sustain. Food Syst. 2014, 38, 722-743. [CrossRef]

9. Clark, S.; Byker, C.; Niewolny, K.; Helms, J. Framing an undergraduate minor through the civic agriculture and food systems curriculum. NACTA J. 2013, 57, 56-67.

10. Galt, R.E.; Clark, S.F.; Parr, D. Engaging values in sustainable agriculture and food systems education: Toward an explicitly values-based pedagogical approach. J. Agric. Food Syst. Community Dev. 2012, 2, $43-54$. [CrossRef]

11. North American Food Systems Network. Degree Programs in Food Systems. Available online: http:/ / foodsystemsnetwork.org/index.php/57-toolbox/for-students / 64-food-system-and-sustainableagriculture-degree-programs (accessed on 12 May 2018).

12. Ericksen, P.J.; Stewart, B.; Dixon, J.; Barling, D.; Loring, P.; Anderson, M.; Ingram, J. The value of a food system approach. In Security and Global Environmental Change; Ingram, J., Ericksen, P., Liverman, D., Eds.; Earthscan: New York, NY, USA, 2010; pp. 25-45. ISBN 978-1-84971-127-2.

13. Meadows, D. Thinking in Systems: A Primer; Chelsea Green Publishing: White River Junction, VT, USA, 2008; ISBN 978-1603580557.

14. Lyson, T.; Stevenson, G.W.; Welsh, R. (Eds.) Food and the Mid-Level Farm: Renewing an Agriculture of the Middle; Massachusetts Institute of Technology Press: Cambridge, MA, USA, 2008.

15. Chindarkar, N.; Thampapillai, D.J. Rethinking Teaching of Basic Principles of Economics from a Sustainability Perspective. Sustainability 2018, 10, 1486. [CrossRef]

16. King, R.P.; Anderson, M.; DiGiacomo, G.; Mulla, D.; Wallinga, D. State Level Food System Indicators; University of Minnesota Healthy Foods Healthy Lives Institute: St. Paul, MN, USA, 2012; (Updated August 2016); Available online: https://www.hfhl.umn.edu/sites/hfhl.umn.edu/files/state_level_food_ system_indicators_report_9-20-16.pdf (accessed on 12 May 2018).

17. Jordan, N.; Grossman, J.; Lawrence, P.; Harmon, A.; Dyer, W.; Maxwell, B.; Cadieux, K.V.; Galt, R.; Rojas, A.; Byker, C.; et al. New curricula for undergraduate foodsystems education: A sustainable agriculture education perspective. NACTA J. 2014, 58, 302-310.

18. Hinrichs, C. Conceptualizing and creating sustainable food systems: How interdisciplinarity can help. In Imagining Sustainable Food Systems: Theory and Practice; Blay-Palmer, A., Ed.; Ashgate Publishing, Ltd.: Burlington, VT, USA, 2010; pp. 17-36. ISBN 978-0754678168.

19. Jordan, N.R.; Bawden, R.J.; Bergmann, L. Pedagogy for addressing the worldview challenge in sustainable development of agriculture. J. Nat. Resour. Life Sci. Educ. 2008, 37, 92-99.

20. Prince, M. Does active learning work? A review of the research. J. Eng. Educ. 2004, 93, 223-231. [CrossRef]

21. Kusano, S.K.; Wright, M.C.; Conger, A.J. Development and Assessment of Self-Agency and the Ability to Innovate and Take Risks; University of Michigan Center for Research on Learning and Teaching: Ann Arbor, MI, USA, 2016; Available online: http:/ / crlt.umich.edu/engaged-learning/sites/default/files/white-papers/ SelfAgency_HI\%20RES.pdf (accessed on 8 May 2018).

22. Galt, R.E.; Parr, D.; Kim, J.V.S.; Beckett, J.; Lickter, M.; Ballard, H. Transformative food systems education in a land-grant college of agriculture: The importance of learner-centered inquiries. Agric. Hum. Values 2013, 30, 129-142. [CrossRef]

23. West, R. Communities of innovation: Individual, group, and organizational characteristics leading to greater potential for innovation. Techtrends 2014, 58, 53-61. [CrossRef]

24. Alexander, P.; Brown, C.; Arneth, A.; Finnigan, J.; Moran, D.; Rounsevell, M.D.A. Losses, inefficiencies and waste in the global food system. Agric. Syst. 2017, 153, 190-200. [CrossRef] [PubMed]

25. Popp, A.; Calvin, K.; Fujimori, S.; Havlik, P.; Humpenöder, F.; Stehfest, E.; Bodirsky, B.L.; Dietrich, J.P.; Doelmann, J.C.; Gusti, M.; et al. Land-use futures in the shared socio-economic pathways. Glob. Environ. Chang. 2017, 42, 331-345. [CrossRef]

26. Arneth, A.; Brown, C.; Rounsevell, M.D.A. Global models of human decision-making for land-based mitigation and adaptation assessment. Nat. Clim. Chang. 2014, 4, 550-557. [CrossRef]

27. Hertel, T.W.; Baldos, U.L.C. Attaining food and environmental security in an era of globalization. Glob. Environ. Chang. 2016, 41, 195-205. [CrossRef] 
28. Kirkwood, C. Systems Dynamics Methods: A Quick Introduction. 1998. Available online: http://www. public.asu.edu/ kirkwood/sysdyn/SDIntro/SDIntro.htm (accessed on 12 May 2018).

29. Kim, D.H. Guidelines for drawing causal loop diagrams. Syst. Thinker 1992, 3, 5-6. Available online: http: / / www.cs.toronto.edu/ sme/SystemsThinking/2014/GuidelinesforDrawingCausalLoopDiagrams.pdf (accessed on 12 May 2018). 